\title{
BENTHIC COMMUNITIES OF SHALLOW-WATER REEFS OF ABROLHOS, BRAZIL
}

\author{
Roberto Villaça ${ }^{1}$ \& Fábio B. Pitombo ${ }^{2}$ \\ ${ }^{1}$ Instituto de Biologia da Universidade Federal Fluminense \\ Departamento de Biologia Marinha \\ (Caixa Postal 100644, 24001-970 Niterói, RJ, Brazil) \\ ${ }^{2}$ Instituto de Biologia da Universidade Federal Rural do Rio de Janeiro \\ (23851-970 Seropédica, RJ, Brazil)
}

- Abstract: The benthic communities of fringing and mushroom-shaped shallow-water reefs of the Abrolhos region (southern coast of Bahia) were surveyed. Line transects were used to estimate coral and algal percentage cover. Mussismilia braziliensis is the most conspicuous coral species in the majority of the communities surveyed, but turf algae make up the dominant cover in all but one studied reef. In general, communities on mushroom-shaped reefs have higher diversity and higher coral cover than on fringing reefs. For both reef morphologies, the coral to alga cover ratio does not show marked differences between annual surveys, despite the high productivity characteristic of the dominant algal species.

- Resumo: Foram estudadas comunidades bentônicas de pouca profundidade nos recifes em franja e chapeirões da região de Abrolhos (costa sul da Bahia). A cobertura das espécies foi estimada pelo método de transect de linha. Mussismilia braziliensis é a espécie de coral mais importante na maioria das comunidades estudadas, porém as algas em tufo são os organismos dominantes em todos os recifes estudados à exceção de apenas um. Em geral, as comunidades nos chapeirões têm maior diversidade e maior cobertura de coral do que as dos recifes em franja. Nos dois tipos de recife, a relação de cobertura coral-alga não apresenta diferença significativa no tempo, apesar da alta produtividade característica do tipo de alga dominante.

- Descriptors: Benthic communities, Coral reefs, Abrolhos, Brazil.

- Descritores: Comunidades bentônicas, Recifes de coral, Abrolhos, Brasil.

\section{Introduction}

The Abrolhos coral reef complex, located off the Eastern coast of Brazil, is the southernmost coral reefs in the Atlantic Ocean. The Abrolhos reefs exhibit several different morphologies (Leão et al., 1985,1988 ), and are mainly characterized by a low coral diversity with a high degree of endemism (Laborel, 1969a, 1969b; Pitombo et al., 1988) what makes this an unique environment.

Despite the ecological importance of this ecosystem, very little is known about its community structure. Part of the reef area of Abrolhos lies within the first Brazilian Marine National Park, "Parque Nacional Marinho dos Abrolhos" (Gonchorosky et al. 1989) created in 1983. Because of the increased concern about the susceptibility of reef ecosystems to global environmental impacts and the need for their conservation, a monitoring project was introduced to study the shallow benthic communities of these reefs. This study is part of a larger monitoring program coordinated by the Marine Park Direction to provide reef conservation.

In the present study, permanent transects were installed for annual monitoring of algal and coral cover between morphologically different reefs with the aim of contributing to the understanding of the community structure of the southernmost coral reefs in the Atlantic Oceann.

\section{Study area}

The Abrolhos reefs are spread over an approximate area of $6.0000 \mathrm{~km}^{2}$ off the south coast of the Bahia State $\left(17^{\circ} 20^{\prime}\right.$ to $18^{\circ} 10^{\prime} \mathrm{S}$ and $38^{\circ} 05^{\prime}$ to 
$39^{\circ} 00^{\prime} \mathrm{W}$ ) (Fig. 1). The reefs are grouped into two arcs: the first is found nearshore (10 to 20 kilometers off the coastline) - Timbebas Reef, Parcel das Paredes Reefs, Coroa Vermelha Reef, Sebastião Gomes Reef, and Viçosa Reef - and the second lies 60 to 70 kilometers offshore, surrounding the Abrolhos Archipelago (Parcel dos Abrolhos Reefs) (Leão et al., 1985, 1988). The prevailing winds blow from the northeast and east during most of the year with speeds ranging from 4 to 15 knots. During the winter, southern winds are common with speeds ranging from 17 to 21 knots. Around the nearshore reefs, the depth of the shelf does not exceed 15 meters but the Parcel dos Abrolhos Reefs area, lie between 20 and $35 \mathrm{~m}$ deep. The water temperature varies from $24^{\circ} \mathrm{C}$ (winter) to $27^{\circ} \mathrm{C}$ (summer) and the tidal amplitude ranges from -0.1 to $2.4 \mathrm{~m}$ throughout the year (Coutinho et al., 1993).

\section{Material and methods}

Sampling was carried out in three periods: January of 1992, December of 1992 and November of 1993. Five samplings sites were defined, three of them were surveyed more than once. A list of transects is shown in Table 1, along with the used codes and depths.

Line transect methodology (Loya, 1972) was used to describe quantitatively the structure of the reef community. Line transects of $10 \mathrm{~m}$ long were placed in characteristic zones of different reefs. A metal pin was fixed in each survey site so that the same transect could be repeated over time.

The following community indices were used:

1 - Relative frequency index $\left(F_{r}=F_{i} / F_{t} \times 100\right)$; where: $F_{i}=$ no. of transects in which a species occurs and $F_{t}=$ total number of transects)

2 - Taxonomic dominance $\mathrm{D}_{\mathrm{T}}=\mathrm{D}_{\mathrm{i}} / 160 \times 100$; where $D_{i}=$ total percentage cover of one taxon in all transects and " 160 " is the total length in meters of all transects.

3 - Index of Importance $\left(I=F_{r} X_{t} / 100\right)$

4 - Shannon diversity (H') and Pielou's eveness (E)(Legendre \& Legendre, 1979)

5 - Functional group dominance $\left(\mathrm{D}_{\mathrm{G}}=\Sigma \mathrm{D}_{\mathrm{i}} \mathrm{X} 100\right.$; where $\Sigma D_{i}$ is the sum of the cover of each taxon that belongs to a Functional group (ex. Coral, Zoanthids, Turf algae, Frondose algae and Crustose coralline algae) in each transect.

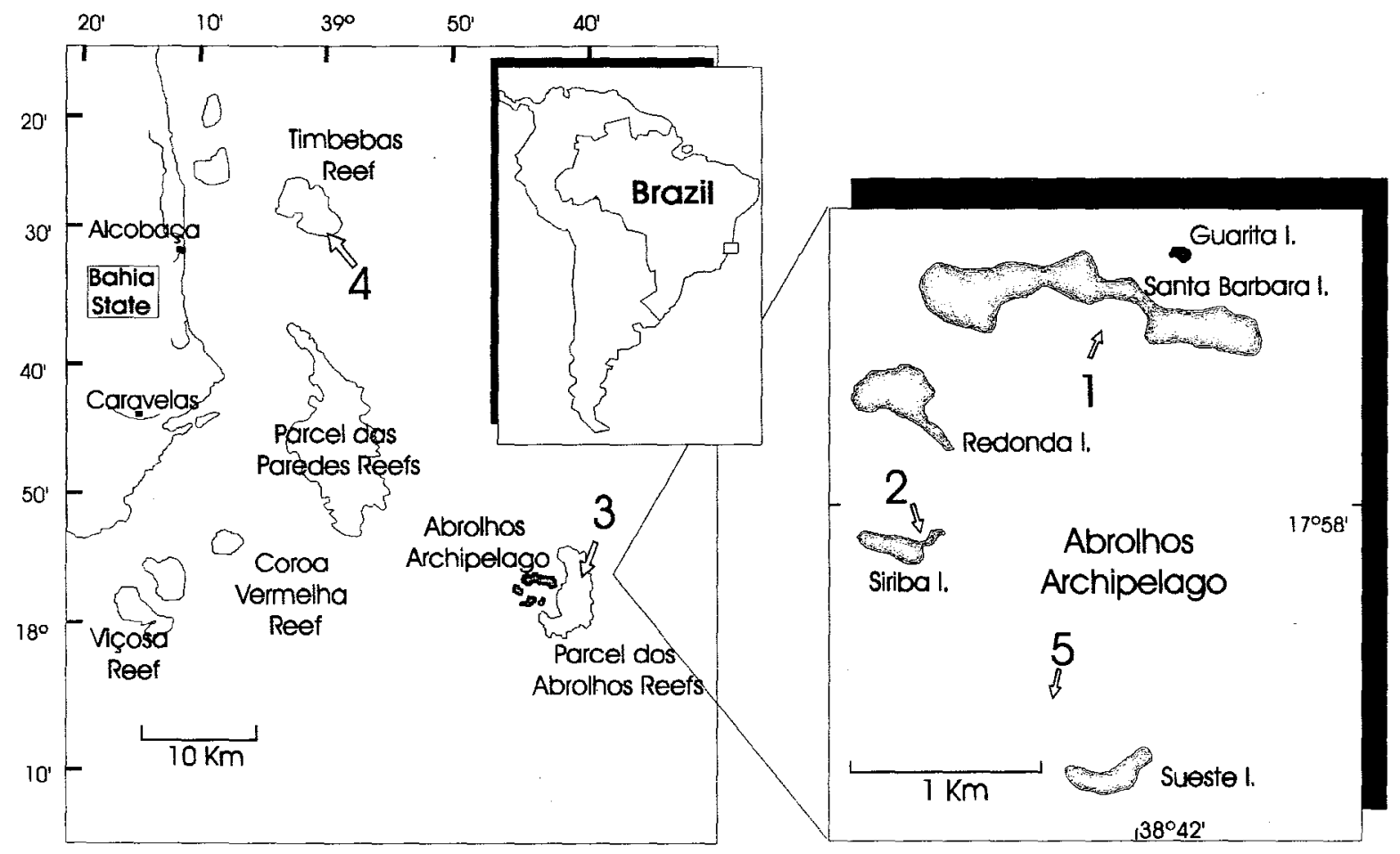

Fig. 1. Map of the Abrolhos region, with the location of the studied reefs. (1) Fringing reef at Santa Barbara Island; (2) Fringing reef at Siriba Island; (3) Mushroom-shaped reef at the Parcel dos Abrolhos Reefs; (4) Mushroom-shaped reef at the southern border of the Timbebas Reef; (5) Mushroom-shaped reef close to Sueste Island of the Abrolhos Archipelago. 
Table 1. Transect location, code used (code), depth (meters) and date of sampling

\begin{tabular}{llcl}
\hline LOCATION & CODE & DEPTH & MONTH \\
\hline Timbebas Reef & TIN3 & 4 & Nov 1993 \\
Sueste Reef & SUN3 & 6 & Nov 1993 \\
Parcel dos Abrolhos Reef & ROD2 & 8 & Dec 1992 \\
Parcel dos Abrolhos Reef & RON3 & 8 & Nov 1993 \\
Santa Barbara I. Coral Zone & BCJ2 & 2.8 & Jan 1992 \\
Santa Barbara I. Coral Zone & BCD2 & 2.8 & Dec 1992 \\
Santa Barbara I. Coral Zone & BCN3 & 2.8 & Nov 1993 \\
Santa Barbara I. Palythoa Zone & BPJ2 & 0.9 & Jan 1992 \\
Santa Barbara I. Palythoa Zone & BPD2 & 0.9 & Dec 1992 \\
Santa Barbara I. Palythoa Zone & BPN3 & 0.9 & Nov 1992 \\
Siriba Island Coral Zone & SCJ2 & 1.9 & Jan 1992 \\
Siriba Island Coral Zone & SCD2 & 1.9 & Dec 1992 \\
Siriba Island Coral Zone & SCN3 & 1.9 & Nov 1993 \\
Siriba Island Algae Zone & SAJ2 & 1.3 & Jan 1992 \\
Siriba Island Algae Zone & SAD2 & 1.3 & Dec 1992 \\
Siriba Island Algae Zone & SAN3 & 1.3 & Nov 1993 \\
\hline
\end{tabular}

The similarity between samples was estimated using the Sørensen index $(S=2 a / b+c$, where $a=$ number of common species among two samples, $b=$ number of species of one sample and $c=$ number of species of the other sample compared) (Legendre \& Legendre, 1979). Cluster analysis using UPGMA strategy was performed by FITOPAC (Sheperd, 1994) software package.

The species abundance and diversity were also calculated for corals but only to compare it with other studies (e.g. Liddell \& Ohlhorst, 1987).

\section{Results}

\section{Qualitative description}

The five surveyed locations are qualitatively described below:

\section{1: Fringing reef at the southern face of Santa Barbara Island}

The profile length was $60 \mathrm{~m}$ ranging from 0 to $4 \mathrm{~m}$ depth. In the first $20 \mathrm{~m}(0.0$ to $0.8 \mathrm{~m}$ depth $)$ the bottom is mainly covered by crustose coralline algae, turf algae and zoanthids. The next $25 \mathrm{~m}$ (0.8 to 2.5 $\mathrm{m}$ depth) are characterized by Palythoa caribaeorum and turf algae. The last $15 \mathrm{~m}$ ( 2 to $4 \mathrm{~m}$ depth) are distinguished by the presence of massive corals and turf algae. The lower level of the profile is covered by frondose algae sparsely distributed (mostly by
Phaeophyta). The $10 \mathrm{~m}$ transects were placed at the Palythoa and in the coral zones.

\section{2: Fringing reef at the northern face of Siriba Island}

This profile was $32 \mathrm{~m}$ long. The substratum is formed by boulders and sand in the first $10 \mathrm{~m}$ ( 0.0 to $0.8 \mathrm{~m}$ depth), with a low density of sessile benthic organisms. The following $13 \mathrm{~m}$ (1.0 to $1.6 \mathrm{~m}$ depth) are marked by dense frondose macroalgae growing on a carbonate sand substratum. The last $10 \mathrm{~m}$ (1.6 to $2.7 \mathrm{~m}$ depth) are characterized by irregular calcareous coralline substratum, massive and encrusting corals, occasional colonies of the gorgonacean Plexaurella regia, turf algae and crustose coralline algae. The $10 \mathrm{~m}$ transects were placed in the algae and in the coral zones.

3: Mushroom-shaped reef at the southern border of the Timbebas reef complex

The top of this reef has approximately $40 \mathrm{~m}$ in diameter and can be subdivided into 3 distinct zones: the eentral flat depression, the crest, and the border. The central flat, with approximately $4 \mathrm{~m}$ deep, is characterized by high coral cover with crustose and turf algae growing between coral colonies. The crest reaches the low tide level and is mainly eovered by crustose coralline algae, vermetid gastropods with the zoanthid Zoanthus spp filling in some crevices. The border zone is covered by the ramose hydrocoral Millepora alcicornis and some massive corals. Downwards the reef top there is a 
very irregular wall profile. The substrate is occupied by encrusting invertebrates (mainly sponges and ascidians), turf and coralline algae, anthipatarians (Anthipates sp) and gorgonians. The transect was placed on the top of the reef in the central flat depression.

\section{4: Mushroom shaped reef at the Parcel dos Abrolhos Reefs}

This reef has a columnar shape of approximately $18 \mathrm{~m}$ in diameter and $12 \mathrm{~m}$ in height. The top of the reef lies at approximately $6 \mathrm{~m}$ depth and it is distinguished by the presence of massive brain corals. In addition, there are turf and crustose coralline algae. Below the border, there is a wall similar to the previously described reef, where different species of corals are seen with a very low rate of cover. Crustose coralline algae and turf algae were present along with other invertebrates like sponges and ascidians. The transect was placed on the top of the reef.

\section{5: Mushroom shaped reef close to Sueste Island}

The reef top had about $10 \mathrm{~m}$ in diameter, and was $9 \mathrm{~m}$ deep. It was mainly covered by turf algae with a moderate cover of massive and encrusting corals and a few colonies of the gorgonacea Phylogorgia dilatata. The walls were mainly covered by turf algae with very low coral coverage. The transect was placed on the top of the reef.

All studied reefs were surrounded by fine sand flats where patches of seagrass and macroalgae beds can be found.

\section{Quantitative community analysis}

A total number of 34 taxa were observed in the line transects, most of all attributed to corals (Scleractinia and Milleporina), soft corals (Zoanthidea) and algae (Table 2). The substrata were completely covered by living organisms and the cover relation between coral and algae varies among the studied zones. As a general pattern, algae were the organism with dominant percentage cover. Table 2 shows the relative frequency, the total dominance and the index of importance (I) for each taxon. Crustose coralline algae (Crustose group) and Gellidium pusillum (Turf group) were the most important species in all studied sites. Furthermore, they were present in almost all surveyed transects. Cyanophyceae was another class of algae with a high index of importance. The most important cnidarian species in the studied communities were Mussismilia braziliensis and Palythoa caribaeorum, although they were only present in 56 and $50 \%$ of the samples, respectively.

Table 2. List of the observed taxa in the line transect; the functional group (EG) proposed for each taxon on this work (corals $=$ Cor; zoanthids $=$ Zoa; turf $=$ Tur, crustose corallinaeae $=\mathrm{Cru}$; frondose $=\mathrm{Fro}$ ), relative frequency $(\mathrm{Fr})$, taxonomic dominance $(\mathrm{Dt})$ and importance Index I.

\begin{tabular}{|c|c|c|c|c|}
\hline Species & $\mathrm{EG}$ & $F_{r}$ & $\overline{D_{t}}$ & I \\
\hline \multicolumn{5}{|l|}{ SCLERACTINIA } \\
\hline Agaricia agaricites & Cor & 62 & 0.4 & 0.25 \\
\hline Favia gravida & Cor & 56 & 0.4 & 0.22 \\
\hline Mussismilia braziliensis & Cor & 56 & 8.9 & 4.98 \\
\hline Montastraea cavernosa & Cor & 18 & 0.4 & 0.07 \\
\hline Mussismilia hartti & Cor & 12 & 0.5 & 0.06 \\
\hline Mussismilia hispida & Cor & 18 & 0.5 & 0.09 \\
\hline Porites astreoides & Cor & 12 & 0.4 & 0.05 \\
\hline Porites branneri & Cor & 18 & 0.1 & 0.02 \\
\hline Siderastrea stellata & Cor & 62 & 1.7 & 1.05 \\
\hline \multicolumn{5}{|l|}{ MLILLEPORINA } \\
\hline Millepora alcicornis & Cor & 19 & 1.3 & 0.25 \\
\hline \multicolumn{5}{|l|}{ ZOANTHIDEA } \\
\hline Palythoa caribaeorum & Zoa & 50 & 12.3 & 6.15 \\
\hline Zoanthus sociathus & Zoa & 50 & 1.7 & 0.85 \\
\hline PORIFERA & & 6 & & \\
\hline CYANOPHYCEAE & Tur & 56 & 17.4 & 9.74 \\
\hline \multicolumn{5}{|l|}{ CHLOROPHYCEAE } \\
\hline Bryopsis pennata & Tur & 6 & 0.1 & 0.01 \\
\hline Caulerpa spp & Tur & 12 & 1.7 & 0.20 \\
\hline Udotea cyathiformis & Fro & 31 & 0.3 & 0.09 \\
\hline \multicolumn{5}{|l|}{ PHAEOPHYCEAE } \\
\hline Dictyota cervicornis & Fro & 25 & 1.5 & 0.38 \\
\hline Dictyota mertensii & Fro & 12 & 0.8 & 0.10 \\
\hline Dictyota sp & Fro & 25 & 0.5 & 0.13 \\
\hline Dietypteris justii & Fro & 18 & 2.6 & 0.47 \\
\hline Dictyopteris plagiogramma & Fro & 12 & 1.5 & 0.18 \\
\hline Lobophora variegata & Fro & 19 & 0.1 & 0.02 \\
\hline Padina santae-crucis & Fro & 37 & 0.4 & 0.15 \\
\hline Sargassum spp & Fro & 25 & 7.3 & 1.83 \\
\hline Stypopodium zonale & Fro & 31 & 1.9 & 0.59 \\
\hline \multicolumn{5}{|l|}{ RHODOPHYCEAE } \\
\hline Amphiroa sp & Tur & 6 & 0.2 & 0.01 \\
\hline Ceramiales & Tur & 43 & 3.2 & 1.38 \\
\hline Corallinaceae & $\mathrm{Cru}$ & 94 & 14.7 & 13.82 \\
\hline Gellidium pusillum & Tur & 93 & 14.4 & 13.39 \\
\hline Hypnea cervicornis & Fro & 6 & $<0.1$ & 0 \\
\hline Jania adhaerens & Tur & 37 & 2.5 & 0.93 \\
\hline Neogoniolithon $\mathrm{sp}$ & Cru & 12 & 0.2 & 0.02 \\
\hline Ochtodes secundiramea & Fro & 6 & $<0.1$ & 0 \\
\hline
\end{tabular}

In order to have a better comparison of community structure from different sites, the taxa were classified in 5 functional groups: hermatipic 
corals, Zoanthidae, crustose coralline algae, frondose algae and turf algae [the algal groups approaching the morphofunctional classification of Littler et al. (1983) and Steneck \& Dethier (1994)]. The dominance of each group in the surveyed transects is shown in Figure 2. Turf algae were the most important group (in \% cover) in the two coral zones of the studied fringing reefs. In the mushroom-like reefs turf algae were also the dominant group in cover, except for Timbebas Reef, where corals were dominant, although corals are the main reef builders in the region along with crustose coralline algae. Coralline algae were not a dominant group in the studied sites, but they were one of the most frequent (Table 2). Despite the lower percent cover, dead coralline crusts are a very important reef substratum in this region. Zoanthids were a conspicuous component of the shallow zone of the Santa Barbara fringing reef (Palythoa zone), and were also present in other areas, especially at Timbebas reef (Fig. 2).

Frondose algae were mostly restricted to the algae zone (Fig. 2) where they presented a very dense cover. This pattern could be observed in some other reefs of the same region.

Three reefs were surveyed more than once, always during summertime. In the Parcel dos Abrolhos Reef, no expressive changes were observed in the community structure. Algae (mainly turf algae) had $60 \%$ cover in the first year (Dec. 92) and $66 \%$ in the following year (Nov. 93); coral cover was $39.4 \%$ and $33.4 \%$, respectively, for the same years (Fig. 2).

Santa Barbara and Siriba Island fringing reefs were surveyed during two consecutive years. The coral zone, in both reefs, show negligible differences concerning alga/coral dominance, except for the samples taken in December 1992 (Fig. 2). These differences were probably due to a measurement error, because it was not possible to locate the transect line in the same exact place as the previous year. However, important differences between coralline and turf algae cover were found in the Santa Barbara reef (Fig. 2). The percentage cover of turf algae in Santa Barbara reef for example, attained more than $80 \%$ in percent cover in the first measurement, around $50 \%$ in the second and in the third sample it was close to $65 \%$. This kind of variation are possibly due to the dynamic of the fast growing filamentous algae which live under heavy herbivorous pressure, and eventually, they might have their biomass completely grazed, a common feature observed in others reefs (Hatcher \& Larkum, 1983).

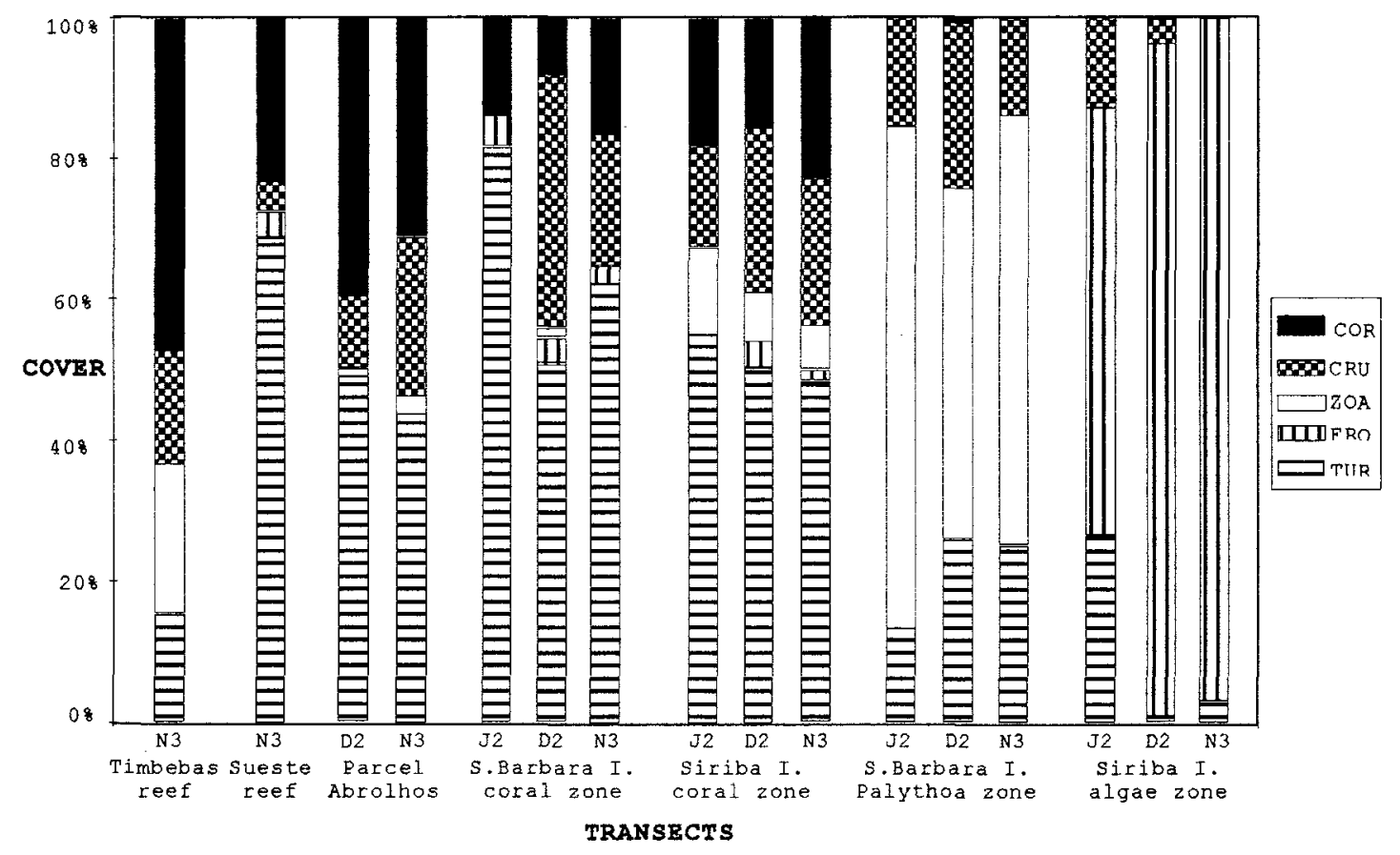

Fig. 2. Percentage of functional group dominance, from the 16 transects: hermatipic corals (Cor), crustose coralline algae (Cru), zoanthids (Zoa), frondose algae (Fro) and turf algae (Tur). 
The Palythoa zone at Santa Barbara Island also showed annual differences both in algae and zoanthids percent cover: $64.2 \%, 50.2 \%$ and $60.8 \%$ for Zoanthids (Palythoa caribaeorum) and 37.6\%, $49.8 \%$ and $39.2 \%$ for algae, respectively, in the last three years. It seems that due to bottom irregularity, very distinct in this zone, it was difficult to repeat sampling exactly at the same previous studied site.

The algae zone at Siriba Island showed very dense cover of frondose macroalgae, mainly Phaeophyta. However, in the second surveyed year, turf algae, especially Gellidium pusillum, accounted for $26.4 \%$ in cover versus 0.7 and $3.05 \%$, respectively, one year before and one year after (Fig. 2).

The reef diversity indices are shown in Table 3. In general, the diversity is higher for the mushroom shape reefs and lower for the Santa Barbara Island reef. Care should be taken in regard to these data, as the turf algal diversity was underestimated. A detailed laboratory observation of a turf from the coral zone of Siriba reef revealed the presence of 13 taxa. In the field, it was only possible to identify the major components of the turf. It is assumed that the same error was introduced in all transects surveyed.

Table 3. Number of species (N); species diversity (H') and Pielou eveness (E) for all taxonomic units, in each transect. Coral species number $(\mathrm{CN})$ species diversity (cH') and eveness $(\mathrm{cE})$ is also presented

\begin{tabular}{ccccccc}
\hline Transect & $\mathrm{N}$ & $\mathrm{H}^{\prime}$ & $\mathrm{E}$ & $\mathrm{cN}$ & $\mathrm{cH}$ & $\mathrm{cE}$ \\
\hline BCJ2 & 9 & 1.22 & 0.39 & 2 & 0.15 & 0.54 \\
BCD2 & 10 & 2.07 & 0.62 & 3 & 0.60 & 0.22 \\
BCN3 & 10 & 1.79 & 0.54 & 3 & 0.22 & 0.20 \\
BPJ2 & 7 & 2.06 & 0.74 & $/$ & $/$ & $/$ \\
BPD2 & 6 & 1.93 & 0.75 & 1 & $/$ & $/$ \\
BPN3 & 6 & 1.70 & 0.66 & $/$ & $/$ & $/$ \\
SAJ2 & 11 & 2.32 & 0.67 & $/$ & $/$ & $/$ \\
SAD2 & 11 & 2.32 & 0.72 & $/$ & $/$ & $/$ \\
SAN3 & 9 & 2.39 & 0.75 & $/$ & $/$ & $/$ \\
SCJ2 & 12 & 2.39 & 0.67 & 5 & 0.86 & 0.53 \\
SCD2 & 14 & 2.19 & 0.58 & 5 & 0.95 & 0.59 \\
SCN3 & 14 & 2.88 & 0.76 & 5 & 0.4 & 0.25 \\
ROD2 & 10 & 2.96 & 0.89 & 3 & 0.72 & 0.66 \\
RON3 & 12 & 2.96 & 0.82 & 5 & 1.02 & 0.63 \\
SUN3 & 15 & 2.60 & 0.66 & 6 & 1.31 & 0.73 \\
TIN3 & 14 & 2.85 & 0.75 & 6 & 0.92 & 0.51 \\
\hline
\end{tabular}

In the Siriba reef algal zone, where frondose macroalgae was the dominant cover, and the underwater identification was easier to perform, the species diversity was very low in comparison with a typical tropical marine flora (Yoneshigue, 1985). The reef diversity using only the coral species, was very low in general but was somewhat higher in the mushroom-shaped reefs (Table 3). Both studied reefs were very shallow not attaining depths below 4 meters. On the other hand the mushroom-like reef transects were positioned in depths always below 4 meters (Table 1). This difference in depth may influence the capacity of some corals species to colonize such shallower environments, consequently reducing their diversity.

The cluster analysis on Sørensen similarity index for all surveyed transects is presented in Figure 3. At 0.5 level it is possible to distinguish 3 major groups: the first one encloses the transects made in the mushroom-shaped reefs and in the coral zones of the Santa Barbara and Siriba fringing reefs; the second group is formed by the transects surveyed at the Palythoa zone of the Santa Barbara fringing reef, and the third group corresponds to the algal zone transects at Siriba Island. At the 0.6 level the first major group is subdivided in two: one group corresponding to the mushroom-shaped reefs, which are segregated from a second group belonging to the fringing reef coral zones, except for one transect placed in a coral zone of Siriba Island.

\section{Discussion}

Many studies of coral reef community structure fail to present data on the algal diversity and coverage, concentrating instead on corals (eg. Loya, 1972; Cantera, 1983; Huston, 1985; Pitombo et al., 1988). Loya (op. cit.) reported high coral cover on different reef zones in the Red Sea ranging from $22 \%$ for depths between 13 to $19 \mathrm{~m}$, to $88 \%$ at $30 \mathrm{~m}$. Cantera (op. cit.) found that coral cover vary from almost zero in the boat channel to $80 \%$ on the fore reef slope on a Colombian fringing reef, but he gave no information about algal cover. Huston (op. cit.) found 8 to $69 \%$ of coral cover in Discovery Bay, Jamaica. Pitombo et al. (op. cit.), found a maximum of $30 \%$ of coral cover at Siriba fringing reef, in Abrolhos. In this study some functional groups other than corals were assessed. Coral together with crustose corallinacea are the main reef builders of the Abrolhos system (see Fig. 2) and the contribution of crustose corallinacea to the bulk of the reef must be evaluated in different reefs in order to have a better understand of this system.

Data from the present study suggest that mushroom-reef tops are qualitatively very similar to the coral zones of fringing reefs (Fig. 3). Two other studied communities, zoanthid and algal zones, have distinctive compositions and must be analyzed separately. Furthermore, line transects do not seem to be the appropriate method for studying frondose algal beds as they have a mobile and tridimensional structure. When quantitative data are included in the 


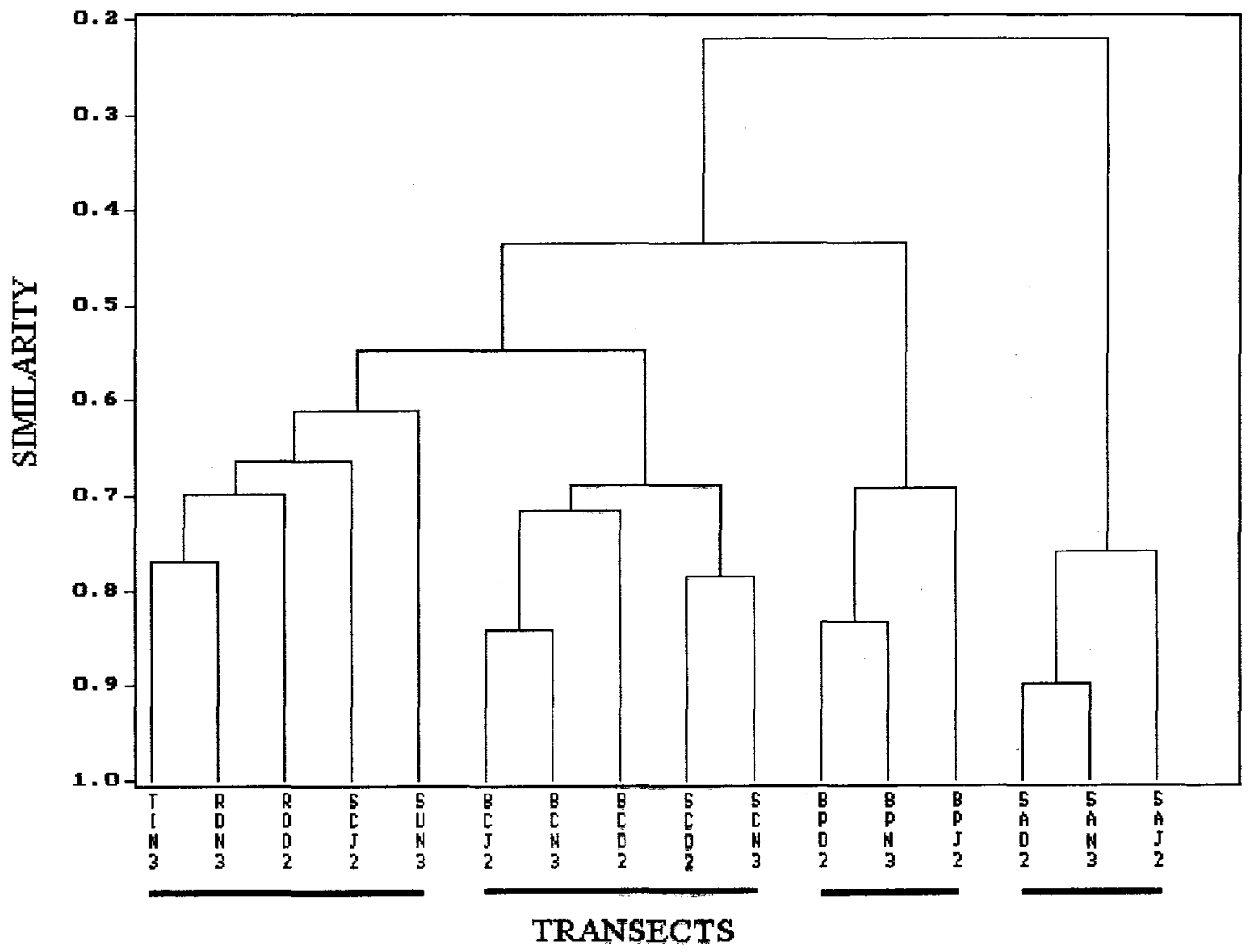

Fig. 3. Cluster analysis of the 16 line transects using UPGMA strategy and Sørensen similarity index, the transects codes are furnished in Table 1.

analysis, some differences appear between the top of mushroom-reefs and the coral zones of fringing reefs. The turf group is more important in the cover of the coral zones (Fig. 2).

Shannon diversity was higher in mushroom reefs with or without algal components (Table 3). For coral species it is clear that besides Mussismilia braziliensis, no other hard coral was important in the cover of fringing reefs. These data agree with the observations of Pitombo et al. (1988). The difference in diversity found among mushroom-like reefs and fringing reefs may be due to reef depths. The fringing reefs are very shallow, not attaining depths higher than 4 meters. In this case, the main constructor coral species cannot develop well, so there is less spatial heterogeneity. In the other hand, mushroom-like reef transects were laid in depths below $4 \mathrm{~m}$ (Table 1), where very complex structures are formed and thus supporting a higher diversity.

The three major studied zones (coral, Palythoa and alga) did not show any marked annual differences. The studied reefs are not affected by storm perturbations. Disturbances caused by hurricanes, that are common to many other reef systems, are unknown in the Abrolhos area.
Therefore, it would be expected that these communities evolved a great stability.

The shallow communities of the Abrolhos reefs are clearly dominated by algae, mainly filamentous turf algae. This pattern is also known in many other reefs (Hatcher \& Larkum, 1983; Klumpp \& McKinnon, 1992). Besides that, most of the filamentous algal cover is mainly composed of Cyanophyceae, suggesting a system with great capacity for fixing nitrogen (Wiebe et al., 1975). The major current in the Abrolhos region is the Brazilian Current, which is poor in nutrients. This may also contribute to the development of the fast growing nitrogen fixing Cyanophyceae which would be an advantage in pour environment. In Paredes Reef, for example, frondose fleshy macroalgae are very abundant in cover and biomass (Coutinho et al, 1993). This reef is localised close to the coast in shallower water, receiving more nutrients inputs from the coastal ecosystems (eg. mangroves and villages) and by sediments ressuspension due to wind driven forces.

Hatcher (1990) hypothesized that many factors such as herbivory, local nutrient concentration, algae defenses effectiveness etc... affect plant biomass on 
coral reefs. Littler \& Littler (1984) stated that nutrient levels and herbivore activity act as two major factors controlling the dominance of benthic primary producers: corals, microfilamentous algae, frondose macroalgae and coralline algae. Herbivory is a common biological factor in structuring reef communities all over the world (review in Steneck, 1988). In the studied reefs, fishes are usually the only population of herbivores which can exert high herbivore pressure. Sea urchins are not very common, even during the night (personal observation). When present, urchins usually stay in protected crevices of dead coralline algae bottoms.

In the present study no specific experiment in herbivory was performed but some speculation could be assumed in the light of the functional group approach (Littler et al., 1983). Considering the relation dominance paradigm of Littler and Littler (op. cit.), the studied reefs are characterized by low nutrient levels and low herbivore activity (dominance of filamentous turf algae). The areas of coral dominance (eg. Timbebas reefs) or patches of crustose coralline (coral zone of fringing reefs) might be under pressure of heavy herbivore activity.

\section{Acknowledgments}

We are grateful to the staff of the Parque Nacional Marinho dos Abrolhos (MNA-IBAMA) that gave us funds and field facilities.

\section{References}

Cantera, J. R. 1983. Distribution des peuplements de scléractiniaires sur un récif frangeant de l'íle de Gorgona (cote Pacifique de Colombie). Téthys, 11:24-31.

Coutinho, R.; Villaça, R.; Magalhães, C. A; Guimaraens, M. A.; Apolinario, M. \& Murici, G. 1993. Influência antrópica nos ecossistemas coralinos da região da Abrolhos, Bahia, Brasil. Acta Biol. Leopoldensia, 15:133-144.

Gonchorosky, J.; Sales, G.; Belém, M. J. C. \& Castro, C. B. 1989. Importance, establishment and management plan of the "Parque Nacional Marinho dos Abrolhos", Brazil. In: Neves, C. ed. Coastlines of Brazil. Part of a series of volumes on Coastlines of the World. New York, American Society of Civil Engineers. p.185194.
Hatcher, B.G. 1990. Coral reef productivity: A hierarchy of pattern and process. Trends Ecol. Evolution, 5:149-155.

Hatcher, B. G. \& Larkum, A. W. D. 1983. An experimental analysis of factors controlling the standing crop of the epilithic algal community on a coral reef. J. expl mar. Biol. Ecol., 69:6184.

Huston, M. 1985. Patterns of species diversity in relation to depth at Discovery Bay, Jamaica. Bull. mar. Sci., 37:928-935.

Klumpp, D. W. \& McKinnon, A. D. 1992. Community structure, biomass and productivity of epilithic algal communities on the Great Barrier Reef: dynamics at different spatial scales. Mar. Ecol. Prog. Ser., 86:77-89.

Leão, Z. M. A. N; Araújo, T. N. F. \& Nolasco, M. C. 1988. The coral reefs off the coast of eastern Brazil. In: Choat, J. H. et al. eds Proceedings of the $6^{\text {th }}$ International Coral Reef Symposium, 3:339-347.

Leão, Z. M. A. N; Bittencourt, A. C. S. P; Dominguez, J. M. L; Nolasco M. C. \& Martin, L. 1985. The effects of Holocene sea level fluctuations on the morphology of the Brazilian coral reefs. Rev. bras. Geoc., 15:154-157.

Laborel, J. 1969a. Madréporaires et Hydrocoraliaires récifaux des cotes Brésiliennes. Systématique, écologie, répartition verticale et géographique. Annls Inst. oceanogr ., 47:171-229.

Laborel, J.1969b. Les peuplements de madreporaires des cotes tropicales du Brésil. Ann Univ Abidjan, ser. E, Ecologie, 2:1-261.

Legendre, L. \& Legendre, P. 1979. Ecologie numerique. Tomme 2. La structure des donnes ecologiques. Paris, Mason. 254p.

Liddell, W. D. \& Ohlhorst, S. L. 1987. Patterns of reef community structure, north Jamaica. Bull. mar. Sci., 40:311-329.

Littler, M. M.; Littler, D. S. \& Taylor, P. R. 1983. Evolutionary strategies in a tropical barrier reef system: functional-form groups of marine macroalgae. J. Phycol., 19:229-237. 
Littler, M. M. \& Littler, D. S. 1984. Models of tropical reef biogenesis: The contribution of algae. In: Round, F. E. \& Chapman, D. J. eds Progress in Phycological Research. Amsterdam, Elsevier Biomedical Press. v. 3, p. 323-364.

Loya, Y. 1972. Community structure and species diversity of hermatypic corals at Eilat, Red Sea. Mar. Biol. 13:100-123.

Pitombo, F. B.; Ratto, C. C. \& Belém, M. J. C. 1988. Species diversity and zonation pattern of hermatypic corals at two fringing reefs of Abrolhos Archipelago, Brazil. In: Choat, J. H. et al. eds. Proceedings of the $6^{\text {th }}$ International Coral Reef Symposium, 2:817-820.

Sheperd, G. J. 1994. FITOPAC 1. Manual do usuário. Universidade Estadual de Campinas, Depto de Botânica.

Steneck, R. S. 1988. Herbivory on coral reefs: a synthesis. In: Choat, J. H. et al. eds. Proceedings of the $6^{\text {th }}$ International Coral Reef Symposium, 1:37-49.
Steneck, R. S. \& Dethier, M. N. 1994. A functional group approach to the structure of algaldominated communities. Oikos, 69:476-498

Wiebe, W. J.; Johanes, R. E. \& Webb, K. L. 1975. Nitrogen fixation in a coral reef community. Science, 188:257-259.

Yoneshigue, Y. 1985. Taxonomie et ecologie des algues marines dans la region de Cabo Frio (Rio de Janeiro, Bresil). Ph.D. Thesis. Université d'Aix-Marseille, Faculte des Sciences de Luminy. 466p.

(Manuscript received 11 April 1997; revised 12 February 1997; accepted 12 March 1997) 